\title{
EFFECTS OF LANDSCAPE GRADIENTS ON WETLAND VEGETATION COMMUNITIES: INFORMATION FOR LARGE-SCALE RESTORATION
}

\author{
Christa L. Zweig and Wiley M. Kitchens \\ Florida Cooperative Fish and Wildlife Unit \\ University of Florida \\ Box 110485, Building 810 \\ Gainesville, Florida, USA 32611-0485 \\ E-mail: czweig@ufl.edu
}

\begin{abstract}
Projects of the scope of the restoration of the Florida Everglades require substantial information regarding ecological mechanisms, and these are often poorly understood. We provide critical base knowledge for Everglades restoration by characterizing the existing vegetation communities of an Everglades remnant, describing how present and historic hydrology affect wetland vegetation community composition, and documenting change from communities described in previous studies. Vegetation biomass samples were collected along transects across Water Conservation Area 3A South (3AS). Ten community types were present between November 2002 and 2005. Separate analyses for key a priori groups (slough, wet prairie, and sawgrass) provided detailed conclusions about effects of historic hydrology on the vegetation of $3 \mathrm{AS}$. Communities were affected by hydrologic variables up to four years previous to the sample. We identified wet prairie/slough species such as Eleocharis spp. and Nymphaea odorata as short-term sentinel species of community change. Sawgrass and $N$. odorata should be monitored for long-term change. Comparisons to preceding studies indicated that many of the communities of previous times, when conditions were drier, no longer exist in our study area and have been replaced by deeper water community types.
\end{abstract}

Key Words: characterization, Everglades, hydrology, multivariate analysis

\section{INTRODUCTION}

The Florida Everglades, an area of global significance, is an example of an ecosystem whose original pattern and process have been irrevocably altered and is currently the focus of a landscape scale restoration effort. Projects of this scope, if they are to achieve the intended restoration, require substantial information regarding ecological mechanisms that are poorly understood. Available information is often outdated, anecdotal, or insufficient to address issues at the multiple scales required. We provide critical information for the restoration of the Everglades and a methodological approach that affords the opportunity to expand knowledge of wetland vegetation pattern beyond the scope of our study area.

The Everglades was once an area characterized by its large spatial extent (1.2 million ha), habitat heterogeneity, sheetflow, and seasonally varying hydrology (Kitchens et al. 2002). Draining, compartmentalization, and agriculture have reduced the spatial extent of the Everglades by $50 \%$ (Light and Dineen 1997). Key drivers such as hydroperiod, fire frequency and intensity, water flow, seasonality, peat accretion, and nutrient inputs were altered, eliminating the wetland's original structure and function. The present hydrology of the area is highly managed and largely disconnected from the natural wet and dry seasons. Natural wet season rainfall initiates in June and extends through September with the driest months in April and May (MacPherson and Halley 1996). However, urban water needs in south Florida require maxima to extend into November and December, and minima from May to July. Conflicting water demands necessitate separate water schedules for the Water Conservation Areas (WCA) within the Everglades, causing some compartments to be overdrained while others are consistently flooded. This differential hydrology fragments the Everglades into a collection of wholly different landscapes that change temporally as well as spatially.

The goal of Everglades restoration is to return the area to a more natural state by reestablishing approximate historic water quantity, quality, and timing, while still providing flood control and water storage for south Florida (Science Subgroup 1994). An important indicator of restoration success will be the response of vegetation communities to the proposed hydrologic alternatives. However, this is a challenging concept because vegetation pattern is 




Figure 1. A hydrograph for Water Conservation Area 3A South from 1978-2004. The solid horizontal line indicates general ground elevation for the area and the dashed vertical lines represent the average stage in $\mathrm{cm}$ for the wet (_ _ - ) and dry (- - - ) eras. The vertical dotted line indicates a transition in water eras in approximately 1991.

dynamic and the exact effects of hydrology and timing on Everglades vegetation community composition are poorly understood. On the short-term temporal scale $(<10$ years), Everglades vegetation patterning is a function of hydrology (Davis 1943, Gunderson 1989, Armentano et al. 2006, Bazante et al. 2006) and disturbances such as fire, hurricanes, and nutrient input (Gunderson 1997). These drivers have created a highly heterogeneous mosaic of vegetation types, where the importance fine-scale gradients in community composition can supersede the control of landscape level elevation and hydrologic gradients. Small changes in elevation, and thus hydrology, at the local level create abrupt changes in vegetation communities (David 1996).

Researchers have documented the response of Everglades vegetation communities to disturbance for decades - from system-wide (Davis et al. 1997) and local levels (Gunderson 1997, Busch et al. 1998) to the response of vegetation to specific disturbances (Craft et al. 1995, Davis 1997, Childers et al. 2003). The most recent comprehensive description of central Everglades vegetation on a landscape scale was by Loveless in 1959, and is often cited to describe the present vegetation communities. Impoundment and water control over the intervening half century have created an altered paradigm (Figure 1) where hydrologic change has had subtle, yet important, effects at the community state level. We believe the vegetation in this region has shifted from the communities described by Loveless to deeper water communities formed by the present wet hydrology, and that identifying the current communities - and specific hydrologic variables that affect them - is the initial step in documenting the effect of restoration hydrologic alternatives on the Everglades ecosystem. We characterize the existing vegetation communities of a central, impounded Everglades remnant, describe how both present and historic hydrology affect wetland vegetation community composition, and document the change from communities described in previous studies, all to provide baseline knowledge for Everglades restoration science.

\section{METHODS}

Study Area

Our study area was a portion of the Everglades in the peninsular region of Florida, USA. Water Conservation Area 3A (WCA 3A) is the largest remnant of the original Everglades, approximately 200,000 ha (Figure 2). Our study area, the southern half of 3A (3AS), is a matrix of tree islands, sawgrass strands (Cladium jamaicense Crantz.), and sloughs, and is designated critical habitat for endangered species such as the Florida snail kite (Rostrhamus sociabilis Vieillot) (Kitchens et al. 2002). Several landscape gradients affect the ecology of 3AS, particularly the vegetation community states (herein referred to as 'communities'). There is an east-west peat depth gradient with peat shallowest on the west side and deepest on the east, and a north-south elevation gradient, with slightly higher elevations in the north, which used to maintain a natural hydrologic gradient. Due to impoundment, there is also an artificial north-south water depth gradient, with deeper depths at the south from pooling, that is currently the main driving factor of plant community structure. Water Conservation Area 3AS is the main focus of Everglades restoration for the next 30 years. The Decompartmentalization and Sheetflow Enhancement Project (DECOMP) will eliminate much of the levee and canal system that now restricts sheetflow in these areas. Approximately $70 \%$ of the eastern levees and canals in $3 \mathrm{AS}$ will be removed, and the highway which forms the southern barrier will be raised to restore natural flow. This is an area that will see radical hydrologic changes in the future and is a critical region for restoration monitoring.

\section{Data Collection}

Data for this analysis are taken from a vegetation monitoring project in 3AS that was initiated in 2002. Twenty $1 \mathrm{~km}^{2}$ plots (Figure 2) were placed in a stratified random manner across the landscape gradients in 3AS. Plots were stratified by the landscape level gradients of peat depth and water depth. Five a priori physiognomic types were 


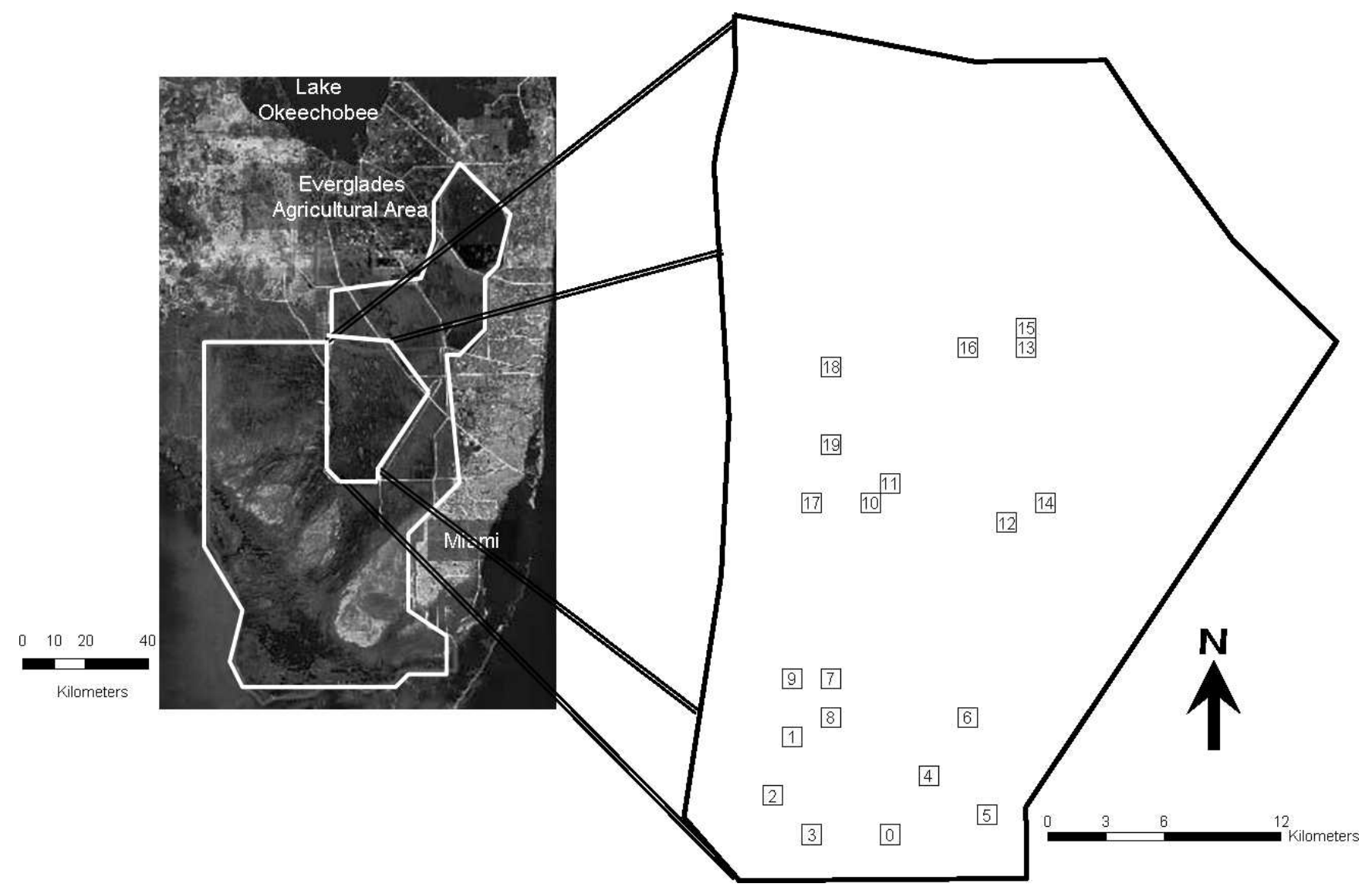

Figure 2. A satellite view of south Florida, USA. The white line indicates general boundaries of the Everglades and Water Conservation Area 3AS, the study site. The locations of study plots are inset.

identified: slough, sawgrass, tree/shrub island, cattail, and wet prairie. Two or three transects in each plot were placed perpendicular to ecotones, beginning in one a priori type and terminating in another, e.g., slough to sawgrass. We collected $0.25 \mathrm{~m}^{2}$ samples of all standing biomass along a belt transect, clipping the vegetation at peat level at $3 \mathrm{~m}$ intervals, and included any submerged aquatic plants within the sample. Shrubs were sampled in the same manner as the herbaceous vegetation; there were no trees in transects. Samples were collected from every transect in every plot during the dry (May/June) and wet season (November/December) of each year. These were sorted by species, counted, dried to a constant weight, and weighed to the nearest $0.1 \mathrm{~g}$. The $0.25 \mathrm{~m}^{2}$ samples represent pseudorepeated measures, as destructive samples were taken and we could not resample the exact location. Approximately 9,500 samples were collected and processed between 2002 and 2005. Our analysis focused on wet season data from the study period, as there were fewer issues of sampling error due to small, new growth and matted prairie vegetation than in the dry season.
Hydrologic data were provided by 17 wells installed in December 2002. On each sample date, water depths were measured with a meter stick at every quadrat and linked to water depth measurements at the nearest well (within a radius $<1 \mathrm{~km}$ ) by subtracting the quadrat water depth from the reading at the well for that day. Historic hydrologic data for all 17 wells-from 1991 to 2002-were hindcast using an artificial neural network model (see Conrads et al. 2006).

To account for high densities of some low biomass species and high biomass of some low density species, data were relativized using an index, importance value (IV), calculated by:

$$
\text { IV for species } \mathrm{i}=\left(\left(\mathrm{R}_{\mathrm{di}}+\mathrm{R}_{\mathrm{bi}}\right) / 2\right) * 100 \text {, }
$$

where $R_{d i}$ is the relative density of species $i$ and $R_{b i}$ is the relative biomass of species i. Relative measures are the sum of biomass or density of species i divided by the sum of biomass or density of all species within the $1 \mathrm{~km}^{2}$ plot. The importance values for all species in a plot sum to 100 . Species that were in $<5 \%$ of the community samples were considered rare and not included in the analysis. 
Table 1. Hydrologic environmental variables used in NMS correlations for Water Conservation Area 3AS. The number refers to the season and timing previous to the sample for which the characteristics were calculated. Max $=$ maximum water depth, Min = minimum water depth, Mean $=$ mean water depth.

\begin{tabular}{llc}
\hline Hydrologic Characteristics & Dry Season & Wet Season \\
\hline MaxPD/MinPD/MeanPD & Previous & One year previous \\
$\begin{array}{l}\text { Max1W/Min1W /Mean1W } \\
\text { Max1D/Min1D/Mean1D }\end{array}$ & One year previous & Two years previous \\
$\begin{array}{l}\text { Max2D/Min2D/Mean2D } \\
\text { Max3W/Min3W/Mean3W }\end{array}$ & Two years previous & Three years previous \\
$\begin{array}{l}\text { Max3D/Min3D/Mean3D } \\
\text { Max4W/Min4W/Mean4W }\end{array}$ & Three years previous & Four years previous \\
Max5W/Min5W/Mean5W & Four years previous & Five years previous \\
\hline
\end{tabular}

\section{Combined Data Analysis}

Our data were designed to be analyzed at several spatial levels - from the physiognomic community using each $0.25 \mathrm{~m}^{2}$ sample to the landscape level by grouping samples. For this analysis, we pooled all data within a $1 \mathrm{~km}^{2}$ plot for each a priori physiognomic type for each year and referred to them as community samples $(\mathrm{n}=234)$. Using PCORD (McCune and Mefford 1999), we performed a hierarchical, agglomerative cluster analysis on the community samples from every plot and year using a relative Sorenson distance measure with a flexible beta of -0.25 . We chose the optimal number of clusters with an indicator species analysis (ISA) (Dufrêne and Legendre 1997) and attempted to identify the associate species for each cluster. Communities were named according to the indicator species from the ISA and their position on the peat and water depth gradient in a non-metric multidimensional scaling ordination (NMS) (Kruskal 1964, Mather 1976). A Multi-Response Permutation Procedure (MRPP) was performed with a Sorenson distance measure to determine the separability of the clusters. MRPP (Mielke and Berry 2001) is a nonparametric test that confirms or rejects the hypothesis of no differences between groups.

We then performed a NMS to determine the environmental factors that affect community composition in 3AS. The NMS was performed using a Sorensen distance measure, 40 runs with real data, and 50 Monte Carlo runs. Environmental variables that represented the major landscape gradients and had the greatest influence on community structure were overlain on the NMS. They included peat depth and a suite of both recent and historic hydrologic variables (Table 1), as they both could affect establishment of plant species (Seabloom et al. 2001). "Recent," for this analysis, is defined as hydrology affecting the area in the past year and "historic" is hydrology $2+$ years previous to the sample event.

\section{A Priori Physiognomic Type Analysis}

Community sample data for 3 of the physiognomic types were analyzed separately (prairie $(\mathrm{n}=47)$, slough $(\mathrm{n}=72)$, and sawgrass $(\mathrm{n}=80))$ using the same procedures described above. These communities were the most abundant and also should exhibit rapid responses to hydrologic alteration due to their herbaceous growth structures. This afforded us the opportunity to further refine our community types and the analysis of the landscape gradients that affect them without the variation associated with data from combined physiognomic types. Stronger gradients for one physiognomic type might overwhelm the more subtle gradients for another, so we separated the data to more fully capture the variation within each physiognomic type. A MRPP analysis corroborated the separation of communities in our a priori groups.

\section{RESULTS}

\section{Combined Data Analysis}

For the combined data, there were 10 plant communities evident from the cluster and indicator species analysis (ISA) - shallow peat wet prairie, shallow peat prairie, slough, longer hydroperiod slough, wet prairie, shrub island, cattail, sawgrass, strand/slough transition, and deteriorated island (Table 2). Results from the MRPP analysis support the separation of these clusters $(\mathrm{T}=-87.65, \mathrm{~A}=$ $0.526, \mathrm{p}<0.0001)$. The T-statistic describes the amount of separation among groups, with the more negative the T-statistic, the more the separation. The A-statistic describes how similar the samples are within each group $(0=$ no agreement, $1=$ perfect agreement), and our data exhibit a relatively high 
Table 2. Percent Importance Value of seven main species for landscape level communities in Water Conservation Area 3A South. $\mathrm{CEO}=$ Cephalanthus occidentalis, CLA = Cladium jamaicense, ELG = Eleocharis elongata, ELC $=$ Eleocharis cellulosa, $\mathrm{NYO}=$ Nymphaea odorata, $\mathrm{PNC}=$ Pontideria cordata, UTsp $=$ Utricularia sp. For some communities, indicator species were not among the main species.

\begin{tabular}{|c|c|c|c|c|c|c|c|}
\hline Community & CEO & CLA & ELG & ELC & NYO & $\mathrm{PNC}$ & UTsp \\
\hline Deteriorated Island & $26.7 \%$ & $16.7 \%$ & $0.4 \%$ & $0.0 \%$ & $1.5 \%$ & $32.9 \%$ & $2.3 \%$ \\
\hline Shrub Island & $53.9 \%$ & $3.0 \%$ & $4.9 \%$ & $0.1 \%$ & $3.3 \%$ & $53.0 \%$ & $2.9 \%$ \\
\hline Sawgrass & $4.2 \%$ & $23.9 \%$ & $15.6 \%$ & $1.5 \%$ & $1.5 \%$ & $3.4 \%$ & $1.5 \%$ \\
\hline Cattail & $1.0 \%$ & $20.0 \%$ & $0.1 \%$ & $17.6 \%$ & $0.9 \%$ & $3.4 \%$ & $1.7 \%$ \\
\hline Wet Prairie & $2.3 \%$ & $2.8 \%$ & $31.0 \%$ & $2.7 \%$ & $20.2 \%$ & $2.6 \%$ & $7.0 \%$ \\
\hline Strand/Slough Transition & $11.7 \%$ & $18.8 \%$ & $7.6 \%$ & $2.8 \%$ & $2.5 \%$ & $3.8 \%$ & $3.9 \%$ \\
\hline Shallow Peat Wet Prairie & $0.0 \%$ & $1.4 \%$ & $6.2 \%$ & $24.0 \%$ & $7.0 \%$ & $0.1 \%$ & $22.9 \%$ \\
\hline Shallow Peat Prairie & $0.0 \%$ & $10.9 \%$ & $1.0 \%$ & $40.6 \%$ & $2.2 \%$ & $0.0 \%$ & $3.4 \%$ \\
\hline Slough & $0.3 \%$ & $0.8 \%$ & $27.4 \%$ & $2.1 \%$ & $18.2 \%$ & $0.1 \%$ & $30.2 \%$ \\
\hline Longer Hydroperiod Slough & $0.0 \%$ & $1.7 \%$ & $5.9 \%$ & $8.6 \%$ & $42.7 \%$ & $0.7 \%$ & $24.2 \%$ \\
\hline
\end{tabular}

within-group agreement. Values for A are often below 0.1 in community ecology (McCune and Grace 2002). Thus, we reject the null hypothesis of no differences among groups.

Plant species richness of the clusters was independent of both the hydrologic variables and peat depth, with a range of 14-23 species in a community cluster (Table 3). Average richness was $20( \pm 2.6)$ species. Slough/strand transition and the sawgrass communities exhibited the highest richness, and the longer hydroperiod slough the lowest.

Spatially, seven of the 10 communities were found across the entire landscape (Figure 3 ). The shallow peat wet and shallow peat prairies were found only in the western portion of the study area, while the longer hydroperiod slough community occurred only in the south and western section of our study area. The most common communities in our sites were the slough and sawgrass strands, reflecting the dominance of these communities on the landscape.

The NMS analysis yielded a three-dimensional solution with a final stress of 10.26 and a Monte Carlo p-value of 0.0196 . The three axes explained
93.4\% of the variance in the data. Axis 1 explained a majority of the variation, with axes 2 and 3 having similar values. The ordination was rotated $10 \mathrm{de}-$ grees for ease of interpretation (Figure 3). Axis 1 corresponded to hydrologic gradients and axis 3 to a peat depth gradient, together explaining $73.6 \%$ of variation in the data. The variables for axis 1 with an $\mathrm{r}$-squared $>0.25$ were Mean $1 \mathrm{~W}(\mathrm{r}=0.603)$, Min $1 \mathrm{~W}$ (0.589), MeanPD (0.567), Min3W (0.551), Min4W (0.537), Max1W (0.537), Mean4D (0.532), Min2W (0.529), Mean3D (0.523), and Mean1D (0.508) (see Table 1 to decipher codes). All but MaxPD, Max3W, Max4W, and Max5W fell above an rsquared $\geq 0.15$ and were positively correlated to axis 1. Peat depth correlated to axis 3 with an r-squared of 0.391. No environmental factors from our analysis were correlated to axis 2 .

\section{A Priori Physiognomic Type Analysis}

The MRPP rejected the hypothesis that community compositions of our a priori groups were identical, confirming their utility for further analyses

Table 3. Community summary statistics for all physiognomic types in Water Conservation Area 3A South. Water and peat depths are in $\mathrm{cm}$.

\begin{tabular}{|c|c|c|c|c|c|c|c|c|}
\hline \multirow[b]{2}{*}{ Community Type } & \multicolumn{3}{|c|}{ Previous wet season } & \multicolumn{3}{|c|}{ Previous dry season } & \multirow{2}{*}{$\begin{array}{c}\text { Species } \\
\text { Richness }\end{array}$} & \multirow{2}{*}{$\begin{array}{l}\text { Peat } \\
\text { Depth }\end{array}$} \\
\hline & Mean & $\operatorname{Max}$ & Min & Mean & $\operatorname{Max}$ & Min & & \\
\hline Deteriorated Island & 36.0 & 58.2 & 11.6 & 10.4 & 43.0 & 7.6 & 21 & 99.2 \\
\hline Shrub Island & 46.0 & 70.4 & 19.8 & 13.4 & 52.7 & 6.7 & 19 & 94.7 \\
\hline Sawgrass & 51.8 & 75.0 & 26.5 & 22.6 & 60.4 & 18.3 & 23 & 108.4 \\
\hline Cattail & 57.0 & 78.6 & 32.3 & 27.4 & 64.9 & 25.3 & 21 & 55.3 \\
\hline Wet Prairie & 61.6 & 89.9 & 32.3 & 34.4 & 84.4 & 24.4 & 21 & 90.2 \\
\hline Strand/Slough Transition & 62.8 & 81.7 & 39.3 & 36.3 & 68.3 & -3.7 & 23 & 101.0 \\
\hline Shallow Peat Wet Prairie & 67.7 & 84.1 & 46.6 & 43.9 & 69.2 & 25.3 & 18 & 55.0 \\
\hline Shallow Peat Prairie & 70.1 & 91.1 & 46.6 & 41.5 & 78.6 & 23.8 & 19 & 38.0 \\
\hline Slough & 74.1 & 93.0 & 51.5 & 44.8 & 73.8 & 31.1 & 20 & 95.4 \\
\hline Longer Hydroperiod Slough & 76.5 & 99.7 & 52.1 & 46.6 & 82.6 & -2.7 & 14 & 83.8 \\
\hline
\end{tabular}




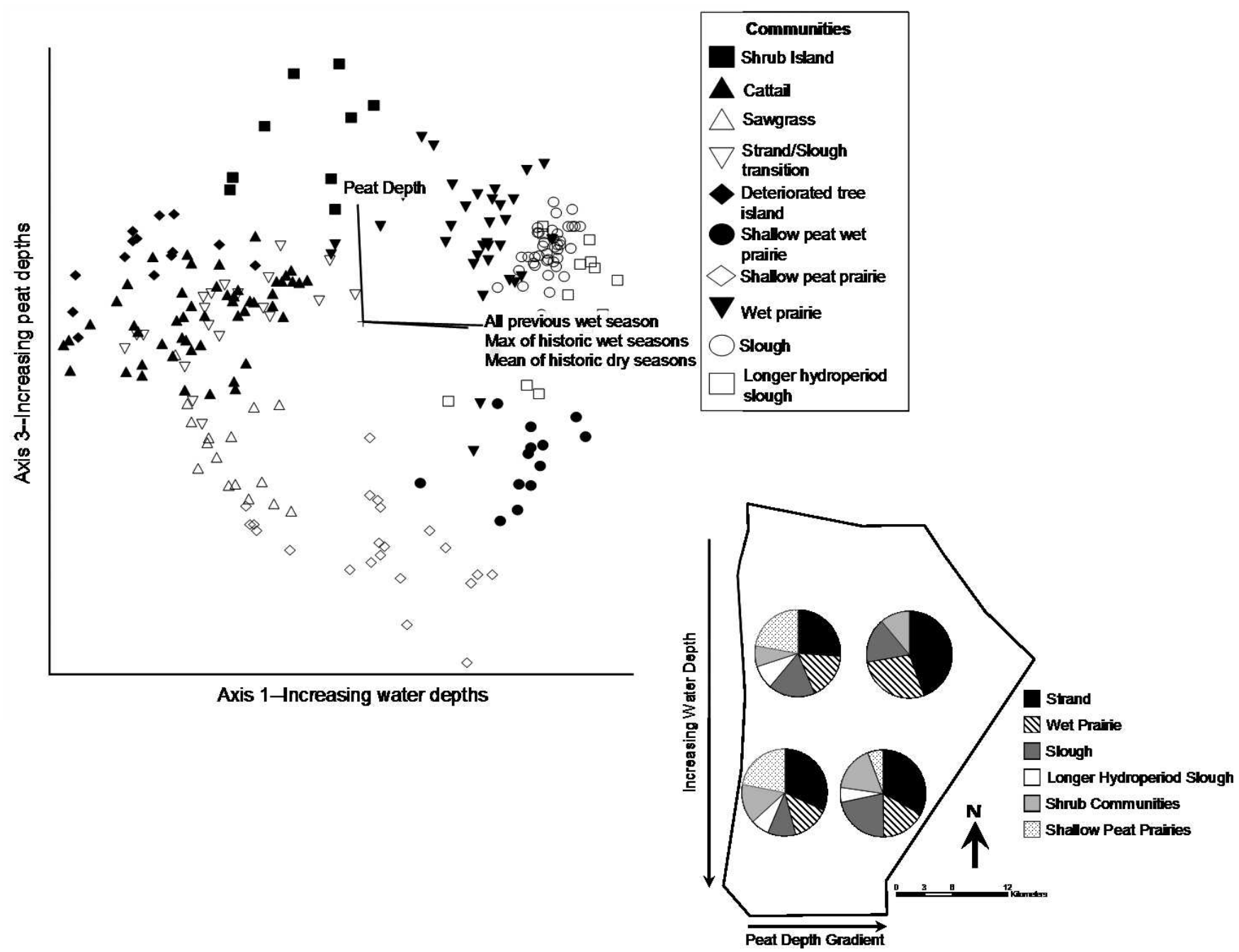

Figure 3. Axis 1 and 3 of the three-dimensional NMS solution for all physiognomic types and spatial distribution of vegetation types in Water Conservation Area 3A South. Some similar communities were combined for ease of interpretation in the spatial element.

$(\mathrm{T}=-76.65, \mathrm{~A}=0.314, \mathrm{p}<0.0001)$. Within-group agreement was high, and between-group agreement was low. We can reject the null hypothesis of no differences among groups.

Prairie analysis. The cluster and indicator species analysis suggested 5 prairie sub-types in our study area: mixed transition prairie; wet prairie; Eleocharis cellulosa Torr. prairie; sparse sawgrass prairie; and Eleocharis elongata Chapman prairie. Spatially, the E. elongata prairie community was located across the whole landscape, while the wet prairie community was found only in the central and west, the E. cellulosa and sparse sawgrass prairie only in the west, and the mixed transition prairie only in the southeast.

The NMS suggested a two-dimensional ordination, with a final stress of 9.57 and Monte Carlo pvalue of $0.0196 ; 95.4 \%$ of the variance in the data was explained by the 2 axes. The ordination was rotated 140 degrees for ease of interpretation (Figure 4a). Axis 1, which correlated to the hydrologic variables, explained $85.3 \%$ of the variation. The vectors in Figure $4 \mathrm{a}$ represent environmental variables with $\mathrm{r}$-squared $\geq 0.15$. Mean2 $(\mathrm{r}=$ -0.412 ) was correlated to axis 1 . Mean8 ( $\mathrm{r}=$ 0.430), Min8 (0.401), and Max8 (0.420) were correlated to axis 2 , which explains $10.1 \%$ of the variance in the data. In summary, the mean water depth of the previous wet season and the mean, minimum, and maximum of the wet season 4 years previous correlated with an axis that explained a large portion of community composition.

Slough analysis. The cluster and indicator species analysis yielded 6 slough sub-types in our study area: shallow slough invaded by sawgrass, lily slough, slough, mixed emergent slough, Eleocharis slough, and hurricane effects. The hurricane effect cluster 



Figure 4. NMS graphs for a priori communities in Water Conservation Area 3A South. A) prairie, B) slough, C) sawgrass. 
Table 4. Biomass and density characteristics of sawgrass sub-communities in Water Conservation Area 3AS.

\begin{tabular}{lccc}
\hline \multicolumn{1}{c}{ Community } & Biomass(g)/quadrat & Stems/quadrat & Biomass(g)/stem \\
\hline Deteriorated Sawgrass Strand & $53.4 \pm 23.51$ & $3.1 \pm 0.52$ & $17.1 \pm 5.98$ \\
Shallow Peat, Short Sawgrass Strand & $69.1 \pm 20.34$ & $4.1 \pm 0.80$ & $16.5 \pm 7.55$ \\
Shallow Peat, Tall Sawgrass Strand & $78.9 \pm 23.57$ & $3.7 \pm 1.11$ & $22.5 \pm 3.32$ \\
Sawgrass with Peltandra & $85.4 \pm 22.23$ & $4.0 \pm 0.88$ & $22.3 \pm 7.55$ \\
Sawgrass with Justicia and Eleocharis & $87.7 \pm 26.34$ & $4.3 \pm 1.3$ & $20.7 \pm 3.32$ \\
\hline
\end{tabular}

only occurred at one time period, after hurricane Wilma, and the main difference in community composition was its lack of Utricularia spp. The high winds from Wilma deposited Utricularia into the strand areas, almost completely removing Utricularia from the sloughs (C. Zweig, pers. obs.). The shallow slough invaded by sawgrass only occurred in the northeast, while the slough and lily slough occurred across the entire study area. The mixed emergent slough community was confined to the western side, and the Eleocharis slough was found only in the southwest. The hurricane effects sub-type was established in all areas, but again only in 2005.

The NMS for slough community sub-types generated a 2-dimensional solution with a final stress of 11.93, a Monte Carlo p-value of 0.196, and $94.4 \%$ of the variance being explained by the 2 axes. The ordination was rotated 50 degrees for interpretation purposes (Figure 4b). Axis 1 correlated to both hydrologic and peat depth variables and explained $46.6 \%$ of the variation. Variables with an $r$-squared $\geq 0.25$ include Mean4D (0.557), Peat Depth (-0.542), Min4D (0.535), Max4D (0.519), Min1W ( $\mathrm{r}=0.509)$, Min5W (0.503), and Mean5W (0.464). No other variable had an r-squared greater than 0.15 for axis 1 . Axis 2 explained $47.8 \%$ of the variation, and was correlated to Min2W $(-0.507)$, Min3W (-0.448), Mean1W (-0.450), Max1W $(-0.435)$, MeanPD (-0.429), and Min1W $(-0.389)$. In summary, a very broad temporal hydrologic range affects community composition of a slough in this area. Peat depth had a large influence on species on a landscape scale. The placement of E. cellulosa in the water depth gradient seems counterintuitive, however, and it highlights the importance of peat depth for species presence and density. For example, E. cellulosa communities were shallow peat communities, but not necessarily shallow water communities as we previously suspected, and can occur in areas of deeper water.

Sawgrass analysis. The cluster and indicator species analysis suggested 5 sawgrass sub-types: deteriorated sawgrass strand; shallow peat, short sawgrass strand; shallow peat, tall sawgrass strand; sawgrass with Peltandra; and sawgrass with E. cellulosa and
Justicia. The labels short and tall were calculated from the average biomass (g) per stem within the community (Table 4). Spatially, the deteriorated strand was found only in the east, while the shallow peat, short strand was found only in the southwest. The other three sub-types were established across the entire landscape.

The NMS of a priori sawgrass community data yielded a 3-dimensional solution (Figure 4c), with a final stress of 11.55 and a Monte Carlo p-value of 0.0196 . The ordination was rotated 40 degrees for ease of interpretation. The 3 axes explained $91.5 \%$ of the variation in the data. Peat depth was correlated to both axis $1(\mathrm{r}=0.507)$ and $3(0.733)$. These two axes explained $26.8 \%$ and $47.6 \%$ of the variation, respectively. Axis 2 was correlated to Max4D and MeanPD and explained $17.2 \%$ of the variation in the data. The environmental variables with an $\mathrm{r}$ squared $>0.15$ were MeanPD $(r=0.396)$ and Max4D (0.416). In summary, peat depth has a strong correlation with sawgrass community composition, as do water depths in the recent and historic (up to 4 years previous) dry seasons.

\section{DISCUSSION}

An objective of this study was to characterize the vegetation communities in WCA 3AS as baseline data for Everglades restoration monitoring. We believe the communities described previously in studies of $3 \mathrm{AS}$ are no longer representative due to the change in overall hydrology (Figure 1). A trend toward Nymphaea-dominated, deep sloughs due to impoundment in the southern end of 3AS was documented by Wood and Tanner as early as 1990 . In approximately 1991, the hydrology of 3AS shifted to the deeper water and extended hydroperiods of the new, wet hydrologic era, and now vegetation communities north of the impoundment effects have changed accordingly.

\section{Hydrologic Correlations}

The hydrologic correlations of each physiognomic group are quite different in regards to season 
Table 5. Summary of temporal and seasonal correlations for the community compositions in 3 physiognomic groups within Water Conservation Area 3AS.

\begin{tabular}{|c|c|c|c|}
\hline & Slough & Sawgrass & Prairie \\
\hline \multicolumn{4}{|c|}{ A. Community Characteristics } \\
\hline Dominant Species & Nymphaea odorata & Cladium jamaicense & Eleocharis spp \\
\hline $\begin{array}{l}\text { Conditions for Optimum } \\
\text { Growth }\end{array}$ & Flooded (Wiersema 1988) & $\begin{array}{l}\text { Requires dry season (Herndon } \\
\text { et al 1991) }\end{array}$ & $\begin{array}{l}\text { Moderately flooded } \\
\text { (Macek et al 2006) }\end{array}$ \\
\hline $\begin{array}{l}\text { Response to Sub-optimal } \\
\text { conditions }\end{array}$ & $\begin{array}{l}\text { Rhizomatous tuber (Zaremba } \\
\text { and Lamont 1993) }\end{array}$ & $\begin{array}{l}\text { Vertical sympodial growth } \\
\text { (Snyder and Richards 2005) }\end{array}$ & $\begin{array}{l}\text { Elongation of stem } \\
\quad \text { (Edwards et al 2003) }\end{array}$ \\
\hline $\begin{array}{c}\text { Consequences of Sub- } \\
\text { optimal conditions }\end{array}$ & $\begin{array}{l}\text { Suspend reproduction, tuber } \\
\text { formation (Zaremba and } \\
\text { Lamont 1993) }\end{array}$ & $\begin{array}{l}\text { Fragmentation, reduced } \\
\text { reproduction (Wu et al 1997, } \\
\text { Snyder and Richards 2005) }\end{array}$ & $\begin{array}{l}\text { Reduced biomass, suspend } \\
\text { reproduction (Macek et } \\
\text { al 2006) }\end{array}$ \\
\hline \multicolumn{4}{|c|}{ B. General Hydrologic Factors } \\
\hline Previous Dry Season & Mean & Mean & \\
\hline Wet 1 Year Previous & Max, Min, Mean & & Mean \\
\hline \multicolumn{4}{|l|}{ Dry 1 Year Previous } \\
\hline Wet 2 Years Previous & Min & & \\
\hline \multicolumn{4}{|l|}{ Dry 2 Years Previous } \\
\hline Wet 3 Years Previous & Min & & \\
\hline \multicolumn{4}{|l|}{ Dry 3 Years Previous } \\
\hline Wet 4 Years Previous & & & Max, Min, Mean \\
\hline Dry 4 Years Previous & Max, Min, Mean & Max & \\
\hline Wet 5 Years Previous & Mean & & \\
\hline
\end{tabular}

(Table 5). The dominant species in each physiognomic type are most sensitive to hydrology during their preferred growing conditions (Edwards et al. 2003, Childers et al. 2006). Species can tolerate harsher conditions in their dormant season, but are more vulnerable to abnormal highs and lows within their growing season. Eleocharis cellulosa's growth improves in moderately flooded, but not high, water conditions (Macek et al. 2006). A wet season with too much or too little water would have an impact on Eleocharis communities, but hydrologic alterations in the dry, dormant season would not.

Temporally, the sub-types within the separate physiognomic types (slough, sawgrass, wet prairie) had correlations that all occurred within one to four years previous to the sample, which indicates a relatively short time lag between hydrologic alteration and vegetation change. Armentano et al. (2006) suggest that Everglades vegetation community response to hydrologic change is normally no more than four years, and our results agree that, for these physiognomic types, the communities respond within four years.

We are not proposing that our environmental variables are the only influences on community composition, but they are representative of the complex hydrology that affects vegetation in $3 \mathrm{AS}$ and provide a basis for experimentation and management. These environmental correlates do not capture all of the variability in the data, and there are probably additional hydrologic characteristics that control the composition of communities, including changes in hydrologic era (dry vs. wet periods) and other long-term hydrologic variables such as duration. Large scale changes due to restoration might alter the determinants of community composition, and thus monitoring should be continuous in order to understand the mechanisms of vegetation change.

\section{Vegetation Communities: Past, Present, and Future}

The Everglades communities we encountered were dynamic and will continue to respond to recent hydrologic alterations. Loveless (1959) described community states of Everglades vegetation that existed in a drier hydrologic era, but his observations are still frequently cited as a benchmark for vegetation restoration in the Everglades. While all of the common species identified by Loveless are still prevalent today, they have rearranged into communities that reflect the present wetter hydrologic era. Rhynchospora flats no longer exist in our study area, nor do extensive Panicum hemitomon Schult. flats (although remnants of the $P$. hemitomon flats were observed outside of our sample locations).

The concept of an Everglades wet prairie in 3AS now needs to include additional definitions. In 1959, there were 3 prairie sub-types dominated by Rhynchospora spp., Panicum spp., and E. cellulosa. In 1990, Wood and Tanner questioned the classification of their sites as wet prairies because they did not contain Rhynchospora spp. We also identified 3 
prairie sub-types in our landscape analysis, but they were dominated by E. elongata, Paspalidium geminatum (Forssk.) Stapf, and E. cellulosa. These do not conform to the original definition of prairie, nor would they be considered sloughs as defined previously (Loveless 1959, Gunderson 1997, Busch et al 1998). Panicum geminatum and E. elongata were located deeper on the hydrologic gradient than $P$. hemitomon in our ordination, so we infer that the community sub-types from our analysis are deeper forms of prairie than those in Loveless (1959). The community sub-types delineated in the separate physiognomic analysis did not have a dominant Panicum or Rhynchospora element. Rhynchospora was rarely encountered, even in dry season samples. Eleocharis has long been considered a slough species in the Everglades (Davis 1943, Loveless 1959, Gunderson 1989, Wood and Tanner 1990), but more recently as conditions became wetter (1991present), it has become accepted as a wet prairie species (Gunderson 1997, Daoust and Childers 1999, Armentano et al. 2006). This suggests that the perception of the Everglades wet prairie - a shortstature graminoid community interspersed among sawgrass - has changed considerably, and the extent of vegetation community transformations within 3AS is more significant than previously recognized.

The only deep water slough described from 3AS prior to our study was a Nymphaea odorata Ait./ Utricularia spp. slough (Loveless 1959, Gunderson 1997). Our combined data analysis suggested two types of slough: Utricularia spp. slough, and a $N$. odorata slough with a longer hydroperiod. The separate physiognomic analysis indicated six subtypes of slough with varying amounts and species of emergents. Species of Eleocharis were abundant in these sloughs, underscoring their role as both slough and prairie vegetation.

The three sawgrass sub-communities that Loveless observed ( $C$. jamaicense/Sagittaria lancifolia L./ P. hemitomon, Myrica cerifera L./Ilex cassine L., and C. jamaicense/P. hemitomon) are not as evident in 3AS in the present water era, and M. cerifera and $I$. cassine were completely absent from sawgrass subcommunities in our study sites. Cephalanthus occidentalis L. and Salix caroliniana Michx. were observed within the deteriorated sawgrass strand sub-type, the only sawgrass community that contained woody species. The five sawgrass subcommunities indicated by the separate physiognomic analyses conform to previous designations of tall and short sawgrass communities, but not necessarily as a function of peat depth, which was thought to be the cause of difference in sawgrass heights (Gunderson 1997). Even though sawgrass is still a dominant plant after decades of impounded, stressful conditions, the sawgrass sub-communities of Loveless' time no longer exist in 3AS.

Vegetation community response depends on the nature and magnitude of the hydrologic alteration, but ecology and life history traits make some species better indicators of either short-term or long-term shifts. Nymphaea odorata and sawgrass are probably slower to respond to hydrologic fluctuations due to their growth structures. Sawgrass is sympodial (Snyder and Richards 2005) and can form tussocks in deeper water, climbing dead roots and culms to reach drier, more hospitable conditions. Sawgrass can maintain its canopy for some time, even while it fragments at the substrate level. Once gone it leaves areas of open water with little other vegetation due to past canopy shading (C. Zweig, pers obs). Longterm flooding will continue to degrade sawgrass strands, but will benefit $N$. odorata. David (1996) states that $N$. odorata is sensitive to dry downs and needs near optimum conditions to persist, making it an excellent indicator for sloughs. However, $N$. odorata is also a rhizomatous perennial that forms dormant root stalks and can survive extended droughts (Zaremba and Lamont 1993), so it is an indicator of both short-term and long-term slough conversion. Eleocharis spp. have less physical structure and respond quickly to hydrologic change, although they have specific responses to alterations in water depth. Eleocharis cellulosa grown in shallow water conditions $(\sim 10 \mathrm{~cm})$ responds to rising water by elongating, but when grown in deeper water $(\sim 50 \mathrm{~cm})$, its response to a rapid drying event is a collapse of the long, thin shoots (Macek et al. 2006), senescence, and complete regrowth (Edwards et al. 2003). It can completely recover within 9 weeks of hydrologic alteration, but recovery by plants in deep water from a precipitous drawdown is slower than that of plants in shallow water (Edwards et al. 2003). Considering species life history characteristics, wet prairie/slough species such as Eleocharis spp. and $N$. odorata are short-term sentinel species of community change, while sawgrass and $N$. odorata should be monitored for long-term change.

We conclude that the wetland vegetation of $3 \mathrm{AS}$ is influenced by both recent and historic hydrology (up to four years earlier), and communities of the mid1900 s no longer exist in our study area. Through a combination of time, anthropogenic activities, and past/current water management actions, the vegetation has changed to communities suited to deeper flooding, with some being eliminated completely. The vegetation communities and correlating hydrologic gradients described in this paper should be considered in future management decisions for 3AS. 


\section{ACKNOWLEDGMENTS}

We thank Paul Wetzel for his insightful comments and editing help. Erik Powers, Zach Welch, and the following provided herculean sampling and sorting efforts: Janell Brush, Becky Hylton, Scott Berryman, Stephen Brooks, Allison Pevler, Patty CastilloTrenn, Kristi Lindgren, Laura Pfenniger, Andrea Bowling, Thea Hotaling, Ann Marie Muench, Chris Cattau, and Julien Martin. The U.S. Corps of Engineers provided funds for the research.

\section{LITERATURE CITED}

Armentano, T. V., J. P. Sah, M. S. Ross, D. T. Jones, H. C. Cooley, and C. S. Smith. 2006. Rapid responses of vegetation to hydrological changes in Taylor Slough, Everglades National Park, Florida, USA. Hydrobiologia 569:293-309.

Bazante, J., G. Jacobi, H. M. Solo-Gabriele, D. Reed, S. Mitchell-Bruker, D. L. Childers, L. Leonard, and M. Ross. 2006. Hydrologic measurements and implications for tree island formation within Everglades National Park. Journal of Hydrology 329:606-19.

Busch, D. E., W. F. Loftus, and O. L. BassJr. 1998. Long-term hydrologic effects on marsh plant community structure in the southern Everglades. Wetlands 18:230-41.

Childers, D. L., R. F. Doren, G. B. Noe, M. Rugge, and L. J. Scinto. 2003. Decadal change in vegetation and soil phosphorus patterns across the Everglades landscape. Journal of Environmental Quality 32:344-62.

Childers, D. L., D. Iwaniec, D. Rondeau, G. Rubio, E. Verdon, and C. J. Madden. 2006. Responses of sawgrass and spikerush to variation in hydrologic drivers and salinity in southern Everglades marshes. Hydrobiologia 569:273-92.

Conrads, P. A., E. Roehls, R. Daamen, and W. M. Kitchens. 2006. Using artificial neural network models to integrate hydrologic and ecological studies of the snail kite in the Everglades, USA. p. 1-8. In Proceedings of the $7^{\text {th }}$ International Conference on Hydroinformatics, Nice, France.

Craft, C. B., J. Vymazal, and C. J. Richardson. 1995. Response of Everglades plant communities to nitrogen and phosphorous additions. Wetlands 15:259-71.

David, P. G. 1996. Changes in plant communities relative to hydrologic conditions in the Florida Everglades. Wetlands 16:15-23.

Davis, J. H., Jr. 1943. The natural features of southern Florida, especially the vegetation, and the Everglades. Florida Geological Survey Bulletin, No. 25.

Davis, S. M. 1997. Phosphorus inputs and vegetation sensitivity in the Everglades. p. 537-78. In S. M. Davis and J. C. Ogden (eds.) Everglades: The Ecosystem and Its Restoration. CRC Press, Boca Raton, FL, USA.

Davis, S. M., L. H. Gunderson, W. A. Park, J. R. Richardson, and J. E. Mattson. 1997. Landscape dimension, composition, and function in a changing Everglades ecosystem. p. 419-44. In S. M. Davis and J. C. Ogden (eds.) Everglades: The Ecosystem and Its Restoration. CRC Press, Boca Raton, FL, USA.

Daoust, R. J. and D. L. Childers. 1999. Controls on emergent macrophyte composition, abundance, and productivity in freshwater Everglades wetland communities. Wetlands 19:262-75.

DeSteven, D. and M. M. Toner. 2004. Vegetation of upper coastal plain wetlands: environmental templates and wetland dynamics within a landscape framework. Wetlands 24:23-42.

Dufrêne, M. and P. Legendre. 1997. Species assemblages and indicator species: the need for a flexible asymmetrical approach. Ecological Monographs 67:345-66.

Edwards, A. L., D. W. Lee, and J. H. Richards. 2003. Responses to a fluctuating environment: effects of water depth on growth and biomass allocation in Eleocharis cellulosa Torr. (Cyperaceae). Canadian Journal of Botany 81:964-75.
Gunderson, L. H. 1989. Historical hydropatterns in wetland communities of Everglades National Park. p. 1099-11. In R. R. Sharitz and J. W. Gibbons (eds.) Freshwater Wetlands and Wildlife Symposium Series No. 61. USDOE Office of Scientific and Technical Information, Oak Ridge, TN, USA.

Gunderson, L. H. 1997. Vegetation of the Everglades: determinants of community composition. p. 323-40. In S. M. Davis and J. C. Ogden (eds.) Everglades: The Ecosystem and Its Restoration. CRC Press, Boca Raton, FL, USA.

Herndon, A., L. H. Gunderson, and J. Stenberg. 1991. Sawgrass (Cladium jamaicense) survival in a regime of fire and flooding. Wetlands 11:17-27.

Kitchens, W. K., R. E. Bennetts, and D. L. DeAngelis. 2002. Linkages between the snail kite population and wetland dynamics in a highly fragmented south Florida hydroscape. p. 183-204. In J. W. Porter and K. G. Porter (eds.) The Everglades, Florida Bay, and Coral Reefs of the Florida Keys: An Ecosystem Sourcebook. CRC Press, Boca Raton, FL, USA

Kruskal, J. B. 1964. Nonmetric multidimensional scaling: a numerical method. Psychometrika 29:1-27.

Laitinen, J., S. Rehell, and J. Oksanen. 2008. Community and species responses to water level fluctuations with reference to soil layers in different habitats of mid-boreal mire complexes. Plant Ecology 194:17-36

Light, S. S. and J. W. Dineen. 1997. Water control in the Everglades: a historical perspective. p. 47-84. In S. M. Davis and J. C. Ogden (eds.) Everglades: The Ecosystem and Its Restoration. CRC Press, Boca Raton, FL, USA.

Loveless, C. M. 1959. A study of the vegetation in the Florida Everglades. Ecology 40:1-9.

Macek, P., E. Rejmánková, and K. Houdková. 2006. The effect of long-term submergence on functional properties of Eleocharis cellulosa Torr. Aquatic Botany 84:251-58.

MacPherson, B. F. and R. Halley. 1996. The South Florida environment - a region under stress. U.S. Geological Survey Circular 1134. U.S. Geological Survey, Branch of Information Services, Denver, CO, USA

Mather, P. M. 1976. Computational methods of multivariate analysis in physical geography. John Wiley and Sons, London, UK.

McCune, B. and J. B. Grace. 2002. Analysis of Ecological Communities. MjM Software, Glenden Beach, OR, USA.

McCune, B. and M. J. Mefford. 1999. PC-ORD: Multivariate analysis of ecological data v. 4.41. MjM Software Design, Medford, OR.

Mielke. JrP. W. and K. L. Berry. 2001. Permutation Methods: A Distance Function Approach. Springer Series in Statistics, Berlin, Germany.

Science Sub-Group. 1994. South Florida ecosystem restoration: scientific information needs. Draft. Management and Coordination Working Group, Interagency Task Force on the South Florida Ecosystem.

Seabloom, E. W., K. A. Moloney, and A. G. van der Valk. 2001. Constraints on the establishment of plants along a fluctuating water-depth gradient. Ecology 82:2216-32.

Snyder, J. M. and J. H. Richards. 2005. Floral phenology and compatibility of sawgrass, Cladium jamaicense (Cyperaceae). American Journal of Botany 92:736-43.

Wierserma, J. H. 1998. Reproductive biology of Nymphaea (Nymphaeaceae). Annals of the Missouri Botanical Garden 75:795-804.

Wood, J. M. and G. W. Tanner. 1990. Graminoid community composition and structure within four Everglades management areas. Wetlands 10:127-49.

Wu, Y., F. H. Sklar, and K. Rutchey. 1997. Analysis and simulations of fragmentation patterns in the Everglades. Ecological Applications 7:268-76.

Zaremba. R. E. and E. E. Lamont. 1993. The status of the coastal plain pondshore community in New York. Bulletin of the Torrey Botanical Club 120:180-87.

Zedler, J. B. 2000. Progress in wetland restoration ecology Trends in Ecology and Evolution 15:402-07.

Manuscript received 10 April 2008; accepted 7 August 2008. 